\title{
Impasses e desafios do processo contemporâneo de globalização
}

\author{
Marina Gusmão de Mendonça ${ }^{1}$
}

O termo globalização, por seu uso indiscriminado, tornou-se, já há algum tempo, quase que desprovido de significado. De fato, a mídia encarregou-se de popularizar de tal forma o vocábulo, que ele freqüenta desde obras teóricas e de caráter analítico mais profundo, quanto conversas descompromissadas de bar e de salão. Ademais, a imprensa especializada em finanças apoderou-se do termo de maneira a levar as pessoas leigas a confundirem-no com mercado financeiro. Todavia, uma recuperação das origens e do verdadeiro significado da palavra, bem como uma reflexão sobre suas implicações faz-se necessária, para que se possa analisar o processo de globalização, que é real, em toda a sua amplitude.

Desse modo, um primeiro aspecto a se abordar diz respeito às origens do conceito de globalização. Com efeito, o termo surgiu no início da década de 1980, disseminado por grandes escolas norte-americanas de administração de empresas, as chamadas business management schools. Sua popularização deu-se a partir de artigos e obras de consultores de estratégia e marketing empresarial, entre os quais destacam-se K. Ohmae e M. E. Porter. Com sua adoção pela imprensa econômica e financeira de língua inglesa, a palavra se difundiu, tendo sido apropriada principalmente pelos grupos neo-liberais.

Nesse processo de difusão do conceito pelas forças do neo-liberalismo, três mensagens às empresas estavam implícitas: que a liberalização e a desregulamentação dos mercados significava o levantamento de todos os obstáculos ao lucro; que as novas tecnologias de comunicação permitiriam extraordinários controles da movimentação do

\footnotetext{
1 Bacharel em História e em Direito pela Universidade de São Paulo; Mestre e Doutora em História Econômica pela Faculdade de Filosofia, Letras e Ciências Humanas da Universidade de São Paulo; Professora Titular de Formação Econômica do Brasil e Formação Econômica da América Latina na Faculdade de Economia e Relações Internacionais da Fundação Armando Álvares Penteado (FAAP); autora de O demolidor de presidentes (Editora Códex) e de Formação econômica do Brasil (Editora Thomson), este último em colaboração com Marcos Cordeiro Pires. 
capital, da produção e da realização de lucros pelas empresas; e, por fim, que haveria uma necessidade urgente de reorganização das empresas em função das novas estratégias internacionais.

Um dos primeiros países a pôr em prática essas advertências e a adotar o termo globalização foi o Japão, onde se procurou eliminar todos os conflitos entre as empresas por meio do estabelecimento de interesses comuns. Disseminou-se, assim, a idéia de um mundo sem fronteiras e de empresas sem nacionalidade.

Já a França procurou uma terminologia própria para designar o processo em curso, adotando a palavra "mundialização" que, no entanto, não foi aceita fora das fronteiras do país e, nem mesmo, em alguns círculos nacionais. Segundo François Chesnais, “o termo de origem francesa 'mundialização' (mondialisation) encontrou dificuldades para se impor, não apenas em organizações internacionais, mesmo que supostamente bilíngües, como a $\mathrm{OCDE}^{2}$, mas também no discurso econômico e político francês. Isso deve-se, claro, ao fato de que o inglês é o veículo lingüístico por excelência do capitalismo e que os altos executivos dos grupos franceses estão entupidos dos conceitos e do vocabulário em voga nas business schools. Mas também, com certeza, ao fato de que o termo 'mundialização’ tem o defeito de diminuir, pelo menos um pouco, a falta de nitidez conceitual dos termos 'global’ e 'globalização’”. E adverte: “a palavra 'mundial’ permite introduzir, com muito mais força do que o termo 'global', a idéia de que, se a economia se mundializou, seria importante construir depressa instituições políticas mundiais capazes de dominar o seu movimento. Ora, isso é o que as forças que atualmente regem os destinos do mundo não querem de jeito nenhum”3.

Todavia, é importante ressaltar que, se o termo tem aproximadamente 20 anos, a idéia relativa a um processo de internacionalização do capital data do início do século XX, quando os primeiros teóricos do imperialismo desenvolveram suas análises a partir da realidade da época, marcada pela expansão territorial e econômica da Europa, pela disputa por mercados e fontes de matérias-primas por parte dos países capitalistas centrais, e pela formação de grandes trusts e cartéis. Passemos, pois, a um retrospecto sobre esses autores e as principais idéias desenvolvidas em suas obras.

\footnotetext{
${ }^{2}$ OCDE: Organização de Cooperação e Desenvolvimento Econômico.

${ }^{3}$ CHESNAIS, François. A mundialização do capital. São Paulo: Xamã, 1996, p. 24. (grifos do autor). 


\section{Origens da crítica à internacionalização do capital: as teorias sobre o imperialismo.}

O primeiro autor a se destacar na análise da internacionalização do capital foi John A. Hobson ${ }^{4}$, que desenvolveu uma reflexão a respeito do imperialismo britânico, assinalando a posição central das finanças no sistema capitalista inglês.

Seguiram-se os autores que, de uma forma ou de outra, estavam ligados à II Internacional. Assinale-se que todos eles concordavam sobre a questão da unidade da economia mundial, na qual se verificava uma integração cada vez mais estreita de todas as suas partes, num sistema de relações moldado pelo capital e dominado pelos países capitalistas centrais. Assim, em 1910, R. Hilferding publicou "O capital financeiro”, em que abordava a dimensão da exportação de valor destinado à produção de mais-valia no exterior (atualmente chamado de Investimento Externo Direto - IED).

A seguir, em 1912, Rosa Luxemburg publicou “A acumulação do capital”6, em que procedia à análise dos mecanismos de centralização de riqueza, que beneficiavam os grandes conglomerados financeiros. Ressaltava, como um desses mecanismos, os empréstimos feitos a Estados semi-coloniais para financiamento de grandes obras de infraestrutura, e destacava a importância da indústria bélica na expansão mundial do capital. E, em 1915, na obra "A economia mundial e o imperalismo", , Bukharin definia a economia mundial como um sistema de relações de produção e de troca, que abrange o mundo todo.

No ano seguinte, Lênin divulgou um de seus textos mais conhecidos "Imperialismo, fase superior do capitalismo"8 -, que constitui uma síntese sobre o conjunto das características do imperialismo. Dentre elas, destacava: o processo de concentração e centralização do capital industrial e a formação de grandes grupos industriais (monopólios); o movimento de concentração e centralização do capital monetário, verificado desigualmente na área dos bancos, e que constituiria a origem do capital financeiro; e a

\footnotetext{
${ }^{4}$ Veja-se: HOBSON, John A. A evolução do capitalismo moderno. São Paulo: Nova Cultural, 1985.

${ }^{5}$ Veja-se: HILFERDING, R. O capital financeiro. São Paulo: Nova Cultural, 1985.

${ }^{6}$ Veja-se: LUXEMBURG, Rosa. A acumulação do capital. São Paulo: Nova Cultural, 1985.

${ }^{7}$ Veja-se: BUKHARIN, N. La economia mundial del imperialismo. Córdoba: Pasado y Presente, 1973.

${ }^{8}$ Veja-se: LENIN, V. I. Imperialismo, fase superior do capitalismo In: Obras escolhidas. São Paulo: AlfaOmega, 1982, v. 1.
} 
importância da exportação de capitais, em contraposição à exportação de mercadorias, o que desencadeava a centralização em favor de países exportadores de capital.

Por fim, Trotsky, no Prefácio de sua obra “A revolução permanente”, , de 1930, considerava a economia mundial como uma poderosa realidade independente, criada pela divisão internacional do trabalho e pelo mercado mundial, que dominava todos os mercados nacionais. Segundo ele, a inserção dos países atrasados e das colônias nessa economia internacional se dava sob a égide do capital financeiro, levando a um desenvolvimento desigual e combinado entre as diversas nações.

Como se vê, todos esses teóricos do imperialismo apontavam para um movimento que, na verdade, já no período entre o final do século XIX (coincidindo, portanto, com a partilha da África e da Ásia) e as primeiras décadas do século XX (marcadas, pois, pela Primeira Guerra Mundial, pela Revolução Russa e pela crise de 1929), era perfeitamente visível, e que correspondia ao processo de internacionalização do capitalismo e de predomínio do capital financeiro.

\section{As críticas contemporâneas}

Dentre os principais críticos da acentuação recente do processo de internacionalização do capital - comumente chamado de globalização -, alguns devem ser mencionados. O primeiro deles é Samir $\operatorname{Amin}^{10}$, que apontou para a expansão do sistema capitalista com base na integração simultânea de três mercados, considerados no âmbito dos Estados-nação: os mercados fornecedores e consumidores, o mercado de capital e o mercado de trabalho. Segundo ele, o processo de mundialização - atente-se para o fato de o autor utilizar a terminologia de origem francesa - leva, na verdade, à eliminação da integração entre os mercados, uma vez que não abrange o trabalho. Dessa forma, as empresas exploram diferenças de remuneração entre as diversas regiões do globo, impondo, ao mesmo tempo, a flexibilização e o rebaixamento dos salários para os operários dos países mais avançados, o que, a longo prazo, gera uma tendência ao alinhamento.

\footnotetext{
${ }^{9}$ Veja-se: TROTSKY, Leon. Prefácio In: A revolução permanente. São Paulo: Ciências Humanas, 1979.

${ }^{10}$ Veja-se: AMIN, Samir. El capitalismo en la globalización. Barcelona: Paidòs, 1999. 
Outro autor a ser destacado é Richard Barnet $^{11}$, que considera a civilização do capitalismo mundializado como um bazar cultural e um centro comercial mundializados (mais uma vez, assinale-se a utilização do termo de origem francesa). Segundo ele, as indústrias de mídia exercem papel extremamente importante no nivelamento cultural e na homogeneização da demanda em nível mundial.

No entanto, Octavio Ianni, em seu livro “Teorias da globalização”, ressalta o caráter histórico do capitalismo e sua tendência para a expansão e para a internacionalização. Segundo ele, “desde que o capitalismo desenvolveu-se na Europa, apresentou sempre conotações internacionais, transnacionais e mundiais, desenvolvidas no interior da acumulação originária do mercantilismo, do colonialismo, do imperialismo, da dependência e da interdependência. E isso está evidente nos pensamentos de Adam Smith, David Ricardo, Herbert Spencer, Karl Marx, Max Weber e muitos outros. Mas é inegável que a descoberta de que o globo terrestre (...) não é mais apenas uma figura astronômica, e sim, histórica, abala modos de ser, pensar, fabular”12. Mas acrescenta: “o problema da globalização, em suas implicações empíricas e metodológicas, ou históricas e teóricas, pode ser colocado de modo inovador, propriamente heurístico, se aceitamos refletir sobre algumas metáforas produzidas precisamente pela reflexão e imaginação desafiadas pela globalização. Na época da globalização, o mundo começou a ser taquigrafado como 'aldeia global’, 'fábrica global’, 'terrapátria', 'nave espacial’, 'nova Babel’ e outras expressões. São metáforas razoavelmente originais, suscitando significados e implicações. Povoam textos científicos, filosóficos, artísticos”13.

Aliás, as metáforas acerca do processo de globalização, usadas pelos diversos autores, são enfatizadas por Renato Ortiz, que aponta para o caráter de novidade do fenômeno e de insuficiência teórica das ciências sociais para explicá-lo. Segundo ele, “chama a atenção nesses textos a profusão de metáforas utilizadas para descrever as transformações deste final de século ${ }^{14}$ : 'primeira revolução mundial’ (Alexander King), 'terceira onda' (Alvin Toffler), ‘sociedade informática' (Adam Schaff), 'sociedade amébica’ (Kenichi Ohmae), ‘aldeia global’ (McLuhan). Fala-se da passagem de uma

\footnotetext{
${ }^{11}$ Veja-se: BARNET, Richard. Global dreams: imperial corporations and the new world order. Nova York: Simon \& Schuster, 1994.

${ }^{12}$ IANNI, Octavio. Teorias da globalização. Rio de Janeiro: Civilização Brasileira, 2000, p. 15.

13 Idem, p. 16.

${ }^{14}$ Evidentemente, o autor se refere ao final do século XX. 
economia de high volume para outra de high value (Robert Reich), e da existência de um universo habitado por ‘objetos móveis’ (Jacques Attali) deslocando-se incessantemente de um lugar a outro do planeta. Por que esta recorrência no uso de metáforas? Elas revelam uma realidade emergente ainda fugidia ao horizonte das ciências sociais” ${ }^{\text {15 }}$.

Quanto à idéia de que a grande novidade da globalização está ligada à disseminação da informação, transformando o planeta numa comunidade global, num mundo sem fronteiras, num shopping center global, numa Disneylândia global, é interessante notar que, já na década de 1970, Marshall McLuhan enfatizava a rapidez com que se transmitiam as informações: "hoje passamos da produção de artigos empacotados para o empacotamento de informações. Antigamente invadíamos os mercados estrangeiros com mercadorias. Hoje invadimos culturas inteiras (...) com pacotes de informações, entretenimentos e idéias. Em vista da instantaneidade dos novos meios de imagem e som, até o jornal é lento" 16 .

Outro aspecto a se salientar, e que foi apontado por Theodore Levitt, diz respeito ao fato de que as diferenças culturais estão desaparecendo, e que o globo todo está ficando semelhante: “em todos os lugares, tudo cada vez mais se parece com tudo o mais, à medida que a estrutura de preferências do mundo é pressionada para um ponto comum homogeneizado" ${ }^{17}$.

No que tange aos aspectos econômicos da globalização, Folker Froebel sublinha ser “evidente que os países em desenvolvimento estão agora oferecendo espaços para a lucrativa manufatura de produtos industriais destinados ao mercado mundial, em escala crescente”. Segundo ele, “isto se deve a vários fatores, entre os quais destacam-se os seguintes: Primeiro, um reservatório de mão-de-obra praticamente inesgotável tornou-se disponível nos países em desenvolvimento nos últimos séculos (...). Segundo, a divisão e subdivisão do processo produtivo estão agora tão avançadas que a maioria destas operações fragmentadas pode ser realizada com um mínimo de qualificação profissional adquirida em pouco tempo (...). Terceiro, o desenvolvimento das técnicas de transporte e comunicações cria a possibilidade, em muitos casos, da produção completa ou parcial de mercadorias em

\footnotetext{
${ }^{15}$ ORTIZ, Renato. Mundialização e cultura. São Paulo: Brasiliense, 1994, p. 14. (grifos do autor).

${ }^{16}$ McLUHAN, Marshall. A imagem, o som e a fúria. São Paulo: Cultrix, 1973, p. 563-570.

${ }^{17}$ LEVITT, Theodore. A imaginação do marketing. São Paulo: Atlas, 1991, p. 43.
} 
qualquer lugar do mundo; uma possibilidade não mais influenciada por fatores técnicos, organizacionais ou de custos”18.

Para Octavio Ianni, de fato, “a fábrica global instala-se além de toda e qualquer fronteira, articulando capital, tecnologia, força de trabalho, divisão do trabalho social e outras forças produtivas. Acompanhada pela publicidade, a mídia impressa e eletrônica, a indústria cultural, misturadas em jornais, revistas, livros, programas de rádio, emissões de televisão, videoclipe, fax, redes de computadores e outros meios de comunicação, informação e fabulação, dissolve fronteiras, agiliza mercados, generaliza o consumismo. Provoca a desterritorialização e a reterritorialização das coisas, gentes e idéias. Promove o redimensionamento de espaços e tempos”. Porém, assinala: “logo se vê que a fábrica global é tanto metáfora como realidade. Aos poucos, sua dimensão real impõe-se ao emblema, à poética. O que se impõe, com força avassaladora, é a realidade da fábrica da sociedade global, altamente determinada pelas exigências da reprodução ampliada do capital. No âmbito da globalização, revelam-se às vezes transparentes e inexoráveis os processos de concentração e centralização do capital, articulando empresas e mercados, forças produtivas e centros decisórios, alianças estratégicas e planejamentos de corporações, tecendo províncias, nações, continentes, ilhas e arquipélagos, mares e oceanos”19.

Esse caráter total da globalização e suas implicações foram questionados por Jorge Luís Borges. Segundo ele, “organizar uma entidade que abarca o planeta não é uma empresa insignificante... Propor uma assembléia que representasse todos os homens seria como fixar o número exato dos arquétipos platônicos, enigma que tem ocupado durante séculos a perplexidade dos pensadores”20.

Max Horkheimer também abordou as questões e implicações envolvidas no caráter total da globalização, que levam à crise das formas conhecidas de pensamento: “a crise da razão se manifesta na crise do indivíduo, por meio da qual se desenvolveu. A ilusão acalentada pela filosofia tradicional sobre o indivíduo e sobre a razão - a ilusão de sua eternidade - está se dissipando. O indivíduo outrora concebia a razão como um instrumento do eu, exclusivamente. Hoje, ele experimenta o reverso dessa auto-deificação. A máquina

18 FROEBEL, Folker et al. The new international division of labour: structural unemployment in industrialized countries and industrialization in developing countries. Cambridge: Cambridge University Press, 1980, p. 13 apud IANNI, Octavio, op. cit., 2000, p. 19.

${ }^{19}$ IANNI, Octavio, op. cit., 2000, p. 19.

${ }^{20}$ BORGES, Jorge Luís. El libro de arena. Madri: Alianza Editorial, 1981, p. 26-27. 
expeliu o maquinista; está correndo cegamente pelo espaço. No momento da consumação, a razão tornou-se irracional e embrutecida. O tema deste tempo é a autopreservação, embora não exista mais um eu a ser preservado"21.

O que se vê, hoje, é uma tecnificação universalizada das relações sociais. O desenvolvimento extensivo e intensivo do capitalismo no mundo levou à generalização da racionalidade formal e real inerente ao modo de operação do mercado, da empresa, do aparelho de Estado, enfim, da administração de tudo. Para tanto, é necessária uma codificação de tudo segundo os princípios do Direito, de forma a permitir o predomínio de valores e fins constituídos no âmbito do mercado. A sociedade, enfim, é vista como um amplo espaço de trocas.

É o que se vê do comentário de Robert Kurz, para quem o que existe, hoje, é a subordinação da razão ao dinheiro. Segundo ele, “a razão universal supostamente absoluta rebaixou-se à mera racionalidade funcional, a serviço do processo de valorização do dinheiro, que não tem sujeito, até a atual capitulação incondicional das chamadas 'ciências do espírito’. O universalismo abstrato da razão ocidental revelou-se como mero reflexo da abstração real objetiva do dinheiro" ${ }^{22}$.

Como se vê, e independentemente da ênfase, os autores concordam sobre alguns aspectos de novidade do recente processo de globalização, que tem transformado não apenas o papel dos Estados e nações, mas também as formas de produção, de pensamento e as próprias relações entre os homens. Passemos agora à análise da questão da permanência do Estado-nação no âmbito do processo de globalização, e que constitui uma de suas mais profundas contradições.

\section{A questão da permanência dos Estados-nação.}

Um dos aspectos mais intrigantes do recente processo de globalização diz respeito à questão dos Estados-nação num contexto de economia e de cultura globalizadas. Para analisá-lo, devemos nos reportar à reflexão de Fernand Braudel sobre as diferenças entre economia mundial e aquilo que ele denominou de economia-mundo.

\footnotetext{
${ }^{21}$ HORKHEIMER, Max. Eclipse da razão. Rio de Janeiro: Editorial Labor do Brasil, 1976, p. 139.

${ }^{22}$ KURZ, Robert. O colapso da modernização. Rio de Janeiro: Paz e Terra, 1992, p. 239. 
De acordo com Braudel, “por economia mundial entende-se a economia do mundo considerado em seu todo, 'o mercado de todo o universo', como já dizia Sismondi. Por economia-mundo, (...) entendo a economia de somente uma porção do nosso planeta, na medida em que essa porção forma um todo econômico. (...) o Mediterrâneo no século XVI era, por si só, uma (...) economia-mundo; podendo igualmente chamar-lhe, em alemão, (...) ‘um mundo em si mesmo’. Uma economia mundo pode definir-se como uma tríplice realidade:

- $\quad$ Ela ocupa um espaço geográfico dado; portanto, tem limites que a explicam e que variam, embora com uma certa lentidão. Ocorrem mesmo, forçosamente, de tempos em tempos, mas a longos intervalos, rupturas. Assim foi após as Grandes Descobertas do final do século XV. Assim foi em 1689, quando a Rússia, pela mão de Pedro o Grande, abriu-se para a economia européia. (...)

- $\quad$ Uma economia-mundo aceita sempre um pólo, um centro, representado por uma cidade dominante, outrora uma cidade-Estado, hoje uma capital econômica (nos Estados Unidos, por exemplo, Nova Yorque, não Washington). Aliás, podem existir, inclusive de modo prolongado, dois centros simultâneos numa mesma economia-mundo: Roma e Alexandria ao tempo de Augusto, Antônio e Cleópatra; Veneza e Gênova ao tempo da guerra pela posse de Chioggia (1378-1381); Londres e Amsterdam, no século XVIII, antes da eliminação definitiva da Holanda. Pois um desses dois centros acaba sempre por ser eliminado. Em 1929, o centro do mundo, com um pouco de hesitação, passou assim, sem ambigüidade, de Londres para Nova Yorque.

Toda a economia-mundo se reparte em zonas sucessivas. O núcleo é a região que se entende em torno do centro: as Províncias Unidas (mas não todas as Províncias Unidas) quando Amsterdam domina o mundo no século XVII; a Inglaterra (mas não toda a Inglaterra), quando Londres, a partir da década de 1780, suplanta definitivamente Amsterdam. Depois, vêm as zonas intermediárias, em torno desse 
núcleo central. Finalmente, muito amplas, as margens que, na divisão do trabalho que caracteriza a economia-mundo, são mais subordinadas e dependentes do que participantes. Nessas zonas periféricas, a vida dos homens evoca freqüentemente o Purgatório, ou mesmo o Inferno. E a razão suficiente disso é, realmente, a sua situação geográfica”23.

Já Immanuel Wallerstein desenvolve a idéia de um “sistema-mundo”. Para ele, "um sistema mundial é um sistema social, um sistema que possui limites, estruturas, grupos, membros, regras de legitimação, e coerência. Sua vida resulta das forças em conflito que o mantêm unido por tensão e provocam sua desagregação na medida em que cada um dos grupos busca eternamente remodelá-lo em seu próprio proveito. Assemelha-se a um organismo, na medida em que tem um certo tempo de vida, durante a qual suas características podem mudar em alguns aspectos e permanecer estáveis em outros. Podemse definir suas estruturas como fortes ou débeis em momentos diversos, tendo em vista a lógica interna de seu funcionamento. (...) até o presente momento têm existido apenas duas variedades desses sistemas mundiais: impérios-mundo, nos quais há um único sistema político sobre a maior parte de uma área, por mais brando que possa ser o controle efetivo, e aqueles nos quais tal sistema único não existe em toda a sua extensão. Por conveniência, e à falta de uma palavra melhor, utilizamos o termo ‘economia-mundo’ para definir os dois últimos. (...) A peculiaridade do sistema mundial moderno é que uma economia-mundo tenha sobrevivido durante quinhentos anos e que ainda não tenha chegado a se transformar em um império-mundo, o que constitui o segredo de sua força. Esta peculiaridade configura-se, do ponto de vista político, na forma de organização econômica daquilo que se denomina capitalismo. Este foi capaz de se desenvolver precisamente porque a economiamundo continha dentro de seus limites não apenas um, mas múltiplos sistemas políticos”24.

Octavio Ianni critica a posição de Braudel e de Wallerstein, porquanto “eles lêem as configurações da história e da geografia como uma sucessão, ou coleção de economiasmundo. Descrevem atenta e minuciosamente os fatos, as atividades, os intercâmbios, os mercados, as produções, as inovações, as tecnificações, as diversidades, as desigualdades,

\footnotetext{
${ }^{23}$ BRAUDEL, Fernand. A dinâmica do capitalismo. Rio de Janeiro: Rocco, 1987, p. 68-70. (grifos do autor).

${ }^{24}$ WALLERSTEIN, Immanuel. El moderno sistema mundial: la agricultura capitalista y los orígenes de la economía-mundo europea en el siglo XVI. México: Siglo Veintiuno, 1979, v. 1, p. 489-491. (tradução nossa). 
as tensões e os conflitos. Apanham a ascensão e o declínio das economias-mundo. Mostram como Veneza, Holanda, Inglaterra, França, Alemanha, Estados Unidos, Japão e os demais países ou cidades, cada um a seu tempo e lugar, polarizam configurações e movimentos mundiais. Permitem reler o mercantilismo, o colonialismo, o imperialismo, o bloco econômico, a geoeconomia, a geopolítica em termos de economias-mundo. Reescrevem a história do capitalismo, como no caso de Wallerstein, ou a história universal, como no de Braudel, em conformidade com a idéia de economia-mundo”.

Segundo ele, “cada vez mais, no entanto, o que preocupa muitos pesquisadores no século XX, em particular depois da Segunda Guerra Mundial, é o conhecimento das realidades internacionais emergentes, ou realidades propriamente mundiais. Sem deixar de continuar a contemplar a sociedade nacional, em suas mais diversas configurações, muitos empenham-se em desvendar as relações, os processos e as estruturas que transcendem o Estado-nação, desde os subalternos aos dominantes. Empenham-se em desvendar os nexos políticos, econômicos, geoeconômicos, geopolíticos, culturais, religiosos, lingüísticos, étnicos, raciais e todos os que articulam e tensionam as sociedades nacionais, em âmbito internacional, regional, multinacional, transnacional ou mundial. A idéia de 'economiasmundo’ emerge nesse horizonte, diante dos desafios das atividades, produções e transações que ocorrem tanto entre as nações como por sobre elas, e além dessas, mas sempre envolvendo-as em configurações mais abrangentes. Quando o pesquisador combina o olhar do historiador com o do geógrafo, logo revelam-se configurações e movimentos da realidade social que transcendem o feudo, a província e a nação, assim como transcendem a ilha, o arquipélago e o continente, atravessando mares e oceanos”.

De acordo com Ianni, "é claro que o pensamento de Braudel e Wallerstein distinguem-se sob vários aspectos, tanto no que se refere ao universo empírico como no relativo ao enfoque teórico. Braudel propõe uma espécie de teoria geral geo-histórica, contemplando as mais diversas configurações de economias-mundo. E está influenciado pelo funcionalismo originário de Durkheim e desenvolvido por Simiand e outros, combinando história, sociologia, geografia, antropologia e outras disciplinas. Ao passo que Wallerstein debruça-se sobre o capitalismo moderno, apoiando-se em recursos metodológicos muitas vezes semelhantes aos do estruturalismo marxista” 25 .

\footnotetext{
${ }^{25}$ IANNI, Octavio, op. cit., 2000, p. 34.

Texto integrante dos Anais do XVIII Encontro Regional de História - O historiador e seu tempo. ANPUH/SP - UNESP/Assis, 24 a 28 de julho de 2006. Cd-rom.
} 
Para Braudel, “a história tradicional, atenta ao tempo breve, ao indivíduo, ao evento, habituou-nos há muito a sua narrativa precipitada, dramática, de fôlego curto. A nova história econômica e social põe no primeiro plano de sua pesquisa a oscilação crítica e assenta sobre sua duração: prendeu-se à miragem, também à realidade das subidas e descidas cíclicas dos preços. Hoje, há assim, ao lado do relato (ou do 'recitativo' tradicional), um recitativo da conjuntura que põe em questão o passado por largas fatias: dez, vinte ou cinqüenta anos. Bem além desse segundo recitativo, situa-se uma história de respiração mais contida ainda, e, desta vez, de amplitude secular: a história de longa, e mesmo, de longuíssima duração. (...) Além dos ciclos e interciclos, há o que os economistas chamam, sem estudá-la, sempre, a tendência secular. Mas ela ainda interessa apenas a raros economistas (...) Entretanto, oferecem útil introdução à história de longa duração. São uma primeira chave. A segunda, bem mais útil, é a palavra estrutura. (...) Por estrutura, os observadores do social entendem uma organização, uma coerência, relações bastante fixas entre realidades e massas sociais. Para nós, historiadores, uma estrutura é, sem dúvida, articulação, arquitetura, porém mais ainda, uma realidade que o tempo utiliza mal e veicula mui longamente. Certas estruturas, por viverem muito tempo, tornam-se elementos estáveis de uma infinidade de gerações: atravancam a história, incomodam-na, portanto, comandamlhe o escoamento. Outras estão mais prontas a se esfacelar. Mas todas são, ao mesmo tempo, sustentáculos e obstáculos”26.

Por sua vez, Wallerstein "focaliza prioritariamente a anatomia e a dinâmica das realidades econômicas e políticas do capitalismo moderno, que denomina capitalismo histórico. São realidades vistas em âmbito nacional e internacional, compreendendo colonialismos, imperialismos, dependências, interdependências, hegemonias, tensões e conflitos. Esse o contexto das guerras e revoluções, destacando-se em especial os movimentos anti-sistêmicos”27.

É o que se vê do comentário de Immanuel Wallerstein: “o capitalismo histórico funcionava numa economia-mundo, mas não num Estado-mundo. Muito pelo contrário. (...) as pressões estruturais militaram contra qualquer edificação de um Estado-mundo. Neste

\footnotetext{
${ }^{26}$ BRAUDEL, Fernand. O Mediterrâneo e o mundo mediterrâneo. Lisboa: Publicações Dom Quixote, 1995. 2 v. (grifos do autor).

${ }^{27}$ IANNI, Octavio, op. cit, 2000, p. 20.

Texto integrante dos Anais do XVIII Encontro Regional de História - O historiador e seu tempo. ANPUH/SP - UNESP/Assis, 24 a 28 de julho de 2006. Cd-rom.
} 
sistema, sublinhamos o papel decisivo dos múltiplos Estados - estruturas políticas as mais poderosas e, ao mesmo tempo, como poder limitado”,28.

Ianni salienta que, para Wallerstein, “a ‘economia-mundo’ está organizada com base no que ele próprio denomina 'capitalismo histórico’, o que Marx havia denominado simplesmente 'capitalismo' ou 'modo capitalista de produção' e Weber denominara ‘capitalismo moderno'. A sua originalidade está em reconhecer que o capitalismo expandiu-se continuamente pelas mais diversas e distantes partes do mundo, o que desafia o pensamento científico do século XX, particularmente nas ciências sociais”29.

Tendo em vista as análises de Braudel e Wallerstein, é importante considerar a questão do fim da guerra fria e seu significado para o sistema capitalista. De fato, a eliminação da polarização capitalismo/EUA, de um lado, e socialismo/URSS, de outro, levou à formação de várias economias-mundo regionais no âmbito da economia-mundo capitalista global.

Todavia, não eliminou os Estados-nação. Na verdade, o capitalismo, como modo de produção e processo civilizatório, permitiu a criação e a recriação do Estado-nação e do princípio da soberania.

Ressalte-se, porém, que o Estado-nação está mudando de figura com a globalização. Segundo Wallerstein, a economia-mundo se tornou, de fato, universal. Todos os Estados nacionais estão, em diferentes graus, integrados em sua estrutura central, estabelecendo-se um padrão de estratificação global, segundo a qual a economia mundial se divide em: áreas centrais, beneficiárias da acumulação; e áreas periféricas, em permanente desvantagem pelo processo de intercâmbio desigual. Porém, mantêm-se realidades locais, nacionais, regionais ou multinacionais, o que leva à permanência de lutas populares, disputas e guerras entre nações e revoluções nacionais e sociais. Ou seja: a economiamundo é de tal forma complexa que transcende a tudo que é local, nacional ou regional.

\footnotetext{
${ }^{28}$ WALLERSTEIN, Immanuel. O capitalismo histórico. São Paulo: Brasiliense, 1985, p. 55.

${ }^{29}$ IANNI, Octavio, op. cit., 2000, p. 22. 


\section{Impasses e desafios}

Diante do que foi exposto, podemos apontar alguns aspectos essenciais do recente processo de globalização e que constituem alguns de seus principais desafios. Primeiramente, deve-se salientar o fato de que o fenômeno correspondente a uma virtualidade do capitalismo, isto é, a algo que estava inscrito na própria lógica do sistema, e que se tornou realidade durante o século $\mathrm{XX}$, ampliando-se sobremaneira depois da Segunda Guerra Mundial.

De fato, durante o período de guerra fria, o capitalismo conheceu uma fase de extraordinário desenvolvimento, tanto intensivo como extensivo. Com isso, impôs-se uma nova divisão internacional do trabalho e a flexibilização dos processos produtivos. Empresas e corporações adquiriram preeminência sobre as economias nacionais. Verificouse um redesenho do mapa, diferente daquele que havia sido imposto pelos Estados-nação, e a intensificação de um processo iniciado no final do século XIX pelos trusts e cartéis, por meio da criação de verdadeiros monopólios.

A liberação das empresas transnacionais dos limites impostos pelos Estados-nação levou a um processo de completa internacionalização do capital, que constitui a base do fenômeno que se costuma definir como fábrica global e shopping center global. Na verdade, o que se verifica dentro da nova divisão internacional do trabalho é uma combinação de fordismo, neo-fordismo, toyotismo, flexibilização e terceirização. Sua difusão ampla foi possível mediante o desenvolvimento sem precedentes da eletrônica, que permitiu levar a uma generalização do capitalismo em termos geográficos e históricos.

Apesar desse movimento, que abarca todo o globo, verifica-se a permanência dos Estados-nação. Isso, contudo, não significa um entrave ao processo. Pelo contrário. A impossibilidade de os governos deixarem de participar do jogo garante fornecimento de força de trabalho constante, barata, disciplinada e submissa. Ademais, a permanência da necessidade de planejamento evita o caos das forças de mercado.

Por outro lado, a metamorfose da ciência em técnica e desta em força produtiva constitui um elemento fundamental do desenvolvimento do modo de produção capitalista, porquanto permite a multiplicação das condições e possibilidades de reprodução ampliada do capital e intensifica o próprio caráter civilizatório do capitalismo. 
Finalmente, e em função da rapidez e da profundidade das transformações, parece estar havendo um esgotamento dos antigos conceitos e das formas conhecidas de interpretação dos fenômenos sociais. A nova sociedade global surge, pois como um novo objeto das ciências sociais, e sua compreensão impõe aos estudiosos a proposição de novos modelos e paradigmas para análise.

A globalização deve, portanto, ser analisada em seus diversos aspectos: como totalidade problemática, complexa e contraditória; como cenário mais amplo de desenvolvimento desigual, combinado e contraditório, isto é, como expressão de diversidades, localismos e identidades, porquanto não há homogeneização, mas, sim, diferenciação em níveis diversos daqueles do passado; como história universal transformada em realidade; e, por fim, como a possibilidade de desenvolvimento de um pensamento global.

\section{Bibliografia:}

AMIN, Samir. El capitalismo en la globalización. Barcelona: Piados, 1999.

ANDERSON, Perry. A crise da crise do marxismo. São Paulo: Brasiliense, 1985.

ANDERSON, Perry. O fim da história (de Hegel a Fukuyama). Rio de Janeiro: Zahar, 1992.

ARBEX, J. Nacionalismo: o desafio da nova ordem pós-socialista. São Paulo: Scipione, 1993.

ARRIGHI, Giovanni. O longo século XX. Rio de Janeiro/São Paulo: Contraponto/UNESP, 1996.

ARRIGHI, Giovanni. A ilusão do desenvolvimento. Petrópolis: Vozes, 1997.

ASH, T. G. Nós, o povo: a revolução de 1989 em Varsóvia, Budapeste, Berlim e Praga. São Paulo: Companhia das Letras, 1990.

ATTALI, Jacques. Milenio. Barcelona: Seix Barral, 1991.

BANDEIRA, Luiz Alberto Moniz. A reunificação da Alemanha. São Paulo: Global, 2001.

BARNET, Richard. Poder global. Rio de Janeiro: Record, 1994. 
BARNET, Richard. Global dreams: imperial corporations and the new world order. Nova York: Simon \& Schuster, 1994.

BAUMAN, Z. Globalização: as conseqüências humanas. Rio de Janeiro: Zahar, 1999.

BERMAN, Marshall. Tudo que é sólido desmancha no ar: a aventura da modernidade. São Paulo: Companhia das Letras, 1986.

BLACKBURN, R., org. Depois da queda: o fracasso do comunismo e o futuro do socialismo. Rio de Janeiro: Paz e Terra, 1993.

BORGES, Jorge, Luis. El libro de arena. Madri: Alianza Editorial, 1981.

BRAUDEL, Fernand. A dinâmica do capitalismo. Rio de Janeiro: Rocco, 1987.

BRAUDEL, Fernand. O Mediterrâneo e o mundo mediterrâneo. Lisboa: Publicações Dom Quixote, 1995. 2 v.

BUKHARIN, N. La economia mundial del imperialismo. Córdoba: Pasado y Presente, 1973.

CAMILLIERI, Joseph A .; FALK, Jim. The end of sovereignity. Hants: Edward Elgar, 1992.

CHANCELLOR, Edward. Salve-se quem puder: uma história da especulação financeira. São Paulo: Companhia das Letras, 2001.

CHESNAIS, François. A mundialização do capital. São Paulo: Xamã, 1996.

CHOMSKY, Noam. Novas e velhas ordens mundiais. São Paulo: Scritta, 1996.

CHOMSKY, Noam. Propaganda e consciência popular. Bauru: EDUSC, 2003.

CHOMSKY, Noam. O que Tio Sam realmente quer. Brasília: UnB, 1999.

CHOSSUDOVSKY, Michel. A globalização da pobreza. São Paulo: Moderna, 1999.

FIORI, J. L.; MEDEIROS, C. Polarização mundial e crescimento. Petrópolis: Vozes, 2001.

FORRESTER, Viviane. O horror econômico. São Paulo: UNESP, 1997.

FROEBEL, Folker et al. The new international division of labour: structural unemployment in industrialized countries and industrialization in developing countries. Cambridge: Cambridge University Press, 1980.

GREIDER, William. O mundo na corda bamba. São Paulo: Geração, 1997. 
HARVEY, David. A condição pós-moderna. São Paulo: Loyola, 1994.

HILFERDING, R. O capital financeiro. São Paulo: Nova Cultural, 1985.

HOBSBAWM, Eric J. A era dos extremos: o breve século XX (1914-1989). São Paulo: Companhia das Letras, 1995.

HOBSBAWM, Eric J. Nações e nacionalismo desde 1780: programa, mito e realidade. Rio de Janeiro: Paz e Terra, 1990.

HOBSBAWM, Eric J. O novo século (entrevista a Antonio Polito). São Paulo: Companhia das Letras, 2000.

HOBSON, John A . A evolução do capitalismo moderno. São Paulo: Nova Cultura, 1985.

HORKHEIMER, Max. Eclipse da razão. Rio de Janeiro: Editorial Labor do Brasil, 1976.

IANNI, Octavio. Teorias da globalização. Rio de Janeiro: Civilização Brasileira, 2000.

IANNI, Octavio. Desafios da globalização. Petrópolis: Vozes, 1999.

IANNI, Octavio. Enigmas da modernidade-mundo. Rio de Janeiro: Civilização Brasileira, 2000.

IANNI, Octavio. A era do globalismo. Rio de Janeiro: Civilização Brasileira, 1996.

IANNI, Octavio. Globalização e a nova ordem internacional In: REIS FILHO, D. A.; FERREIRA, J.; ZENHA, C., org. O século XX, o tempo das dúvidas: do declínio das utopias às globalizações. Rio de Janeiro: Civilização Brasileira, 2000.

JAMESON, F. Pós-modernismo: a lógica cultural do capitalismo tardio. São Paulo: Ática, 1997.

KENNEDY, Paul. Ascensão e queda das grandes potências: transformação econômica e conflito militar de 1500 a 2000. Rio de Janeiro: Campus, 1989.

KLIKSBERG, B. Como transformar al Estado? México: Fondo de Cultura Económica, 1993.

KURZ, Robert. O colapso da modernização. Rio de Janeiro: Paz e Terra, 1992.

LENIN, V. I. Imperialismo, fase superior do capitalismo In: Obras escolhidas. São Paulo: Alfa-Omega, 1982, v.1.

LEVITT, Theodore. A imaginação do marketing. São Paulo: Atlas, 1991.

LUXEMBURG, Rosa. A acumulação do capital. São Paulo: Nova Cultural, 1985. 
McLUHAN, Marshall. A imagem, o som e a fúria. São Paulo: Cultrix, 1973.

NERE, Jacques, org. História contemporânea. Rio de Janeiro: Bertrand Brasil, 1988.

OFFE, Claus. Capitalismo desorganizado. São Paulo: Brasiliense, 1994.

ORTIZ, R. Um outro território: ensaios sobre a mundialização. São Paulo: Olho d'água, 1996.

ORTIZ, R. Mundialização e cultura. São Paulo: Brasiliense, 1994.

RAMONET, I. G. A desordem das nações. Petrópolis: Vozes, 1996.

RIFKIN, J. O fim dos empregos. São Paulo: Makron, 1996.

SANTOS, M., org. O novo mapa do mundo: o fim do século e globalização. São Paulo: Hucitec, 1993.

SARAIVA, J. F. S., org. Relações internacionais contemporâneas: da construção do mundo liberal à globalização. Brasília: Paralelo 15, 1997.

SECO, Juan Francisco Martín. La farsa neoliberal. Madri: Temas de Hoy, 1995.

TAVARES, Maria da Conceição; FIORI, José Luís. Poder e dinheiro: uma economia política da globalização. Petrópolis: Vozes, 1997.

TROTSKY, Leon. Prefácio In: A revolução permanente. São Paulo: Ciências Humanas, 1979.

VIZENTINI, P. G., org. A grande crise: a nova (des)ordem dos anos 80 e 90. Petrópolis: Vozes, 1992.

WALLERSTEIN, Immanuel. O capitalismo histórico. São Paulo: Brasiliense, 1985.

WALLERSTEIN, Immanuel. El moderno sistema mundial: la agricultura capitalista y los orígenes de la economía-mundo europea en el siglo XVI. México: Siglo Veintiuno, 1979. 2 v. 